\title{
The Student Teacher as Person: Reflections on Pedagogy and Being
}

Francine H. Hultgren

University of Maryland

Clearly there is a need for the recognition of teachers, not as things, but as beings. Things can be described, defined, fragmented, measured, controlled. Things do not change from within. Things can perform actions, but they do not experience. Beings, on the other hand, actively describe, define, seek wholeness, elude measurement, pursue freedom. Beings change and grow and experience. Things do. Beings not only do, but are. (Cunningham, 1983, p. 18)

This paper is an attempt to display my inquiry into a being focus with the student teaching experience, but prior to getting there, the doing focus is contrasted for its different assumptions and inherent outcomes.

Teaching, traditionally, has been viewed as doing rather than being. The doing is a reflection of the dominant technocratic rationality and knowledge base in teacher education which is exemplified in thing-like qualities (behavioral competencies from the field of educational psychology) that can be performed and then measured. The socialization process in becoming a teacher from such a view gives emphasis to the mastery of technical skills which tend to separate the act of teaching from the person who is doing the acting (teaching). Talk about teaching from this perspective takes the form of learning, management, competencies, evaluation, teaching techniques, classroom discipline, and control. Student teaching is viewed as survival in an apprenticeship (May \& Zimpher, 1985; Adler, 1984; Tom, 1985), wherein the purpose is to apply effectively the knowledge base and principles learned in professional education courses. Concepts and terms learned in these courses have come, for the most part, from the social and behavioral sciences (patterned after the natural sciences), wherein the emphasis is on explanation of roles and behaviors. The result is to be concerned with the why before we know the is of teaching. This objective mode of understanding is a deficient mode of seeing human beings. What then is called for if we are to move beyond a doing approach to teaching and give expression to the teacher as person, a being in the process of becoming?

Denton (1974) describes teaching as a mode of being-in-the-world, and suggests that "If we seek understanding of a being-who-teaches from within the situation, the meaning of the particular will be obtained from the teacher in her work with others, not from some 
a priori law" (p. 102). He argues that most of the literature on teaching neglects the lived reality of the classroom, the existential component of the being-who-teaches, in favor of giving attention to explanatory causes in terms of variables which have been defined in terms of what we will see or not see in relation to some theory. Phenomena not accounted for by theory, then, are screened out. To see the lived world, he says, we have to put aside two common notions of seeing: First, learned stereotypes or projections of subjective selfhood, and second, passive seeing that is analogous to a camera's receptivity. He calls for existential seeing or a seeing of what is as it is experienced, as opposed to that which is observed. This kind of seeing is made possible through phenomenological research: the study of lived experience.

In turning to phenomenology we ask the question, "What is a particular experience like?" Insightful descriptions are sought of the way in which the world is experienced rather than as it is conceptualized, categorized, or theorized. Van Manen (1984) describes phenomenological inquiry by way of the following aspects: (a) It is the study of essences (the very nature of the phenomena); (b) It is the attentive practice of thoughtfulness (a heedful, mindful wondering); (c) It is a search for what it means to be human (a taking into account of the traditions which have given meaning to our way of being in the world); (d) It is a poetizing activity (a thinking on original experience-the voice that stands behind the experience). As such, it is an attempt to discover what lies at the core of our being.

The phenomenological question in regard to teaching then is, "What does it mean to be a teacher?" In regard to my particular interest, I am asking "What does it mean to be a student teacher?" "What is it like to experience student teaching?" My initial turning to this question occurred in my dissertation inquiry (Hultgren, 1982), wherein I sought to bring forth the disclosure of being with student teachers in providing a grounding for curriculum questions and educational experiences. In that pursuit, the lived experiences in student teaching and curriculum were the phenomena I sought to uncover, to gain access to existential themes in their being as teachers. My present research is an attempt to act on the insights gained and recommendations made for action with student teachers from that inquiry.

The intent of phenomenological inquiry is that based on research results, one seeks to formulate recommendations that might lead to more possibilities for human autonomy and a better situation for those who are affected by a decision or course of action-in this case student teachers. My recommendations called for continued recognition and drawing out of the following themes in work with student teachers (Hultgren, 1982, pp. 184, 185). 
Authenticity. Inauthentic existence is called into being by commanding/ obeying relationships. When students are inauthentically there, they are guided by role expectations rather than assuming responsibility for their own existence; they are alienated from the world and their own possibilities for being in it. Supervisory and teaching encounters with teachersto-be must allow being to emerge rather than focusing on performance. The transfer of responsibility to the impersonal they through obeying must be brought back to the student teacher. The challenge is to find ways to lead students back to themselves authentically.

The mood of anxiety. In leading students to be authentically, confrontation with their own potentiality of becoming requires meeting anxiety head on. We are accustomed generally to think of anxiety as undesirable, or we flee in the face of anxiety as described by Heidegger. Existential anxiety is not so to be regarded. The mood of anxiety can reveal something about a student teacher's self-realization, and as such, can open the way for disclosure and encountering of something that matters, the power of becoming.

Existentiality. The ultimate sense of freedom or autonomy is existentiality according to Heidegger, because the self, in transcending toward its potentiality, makes itself free for possibilities. The use of existential descriptions to break with predefined categories of thought helps to open new possibilities, then, by seeing in new ways. Teaching as a mode of being requires entry into that experiential world of existential themes.

In essence, my action entailed an explicit attempt to reconceptualize the course I teach along with the student teaching experience, so as to reflect a phenomenological framework for student teaching. This was my departure point to gain access to the is of student teaching - the lifeworld experiences of the student teachers so as to provide new possibilities for understanding, and to raise additional questions that can help address a critical approach to teacher education. The course I taught at the university met for the first eight weeks of the student teaching semester, twice a week for three hours in the afternoons. Throughout these first eight weeks the student teachers were also out in their schools teaching in the mornings, which allowed ideal opportunity for reflection and dialogue on their experiences. The second eight weeks of the semester were spent student teaching full days out in the schools. The following is an excerpt of the course syllabus which reflects the phenomenological focus (Hultgren, 1985):

Reflective teaching will be the instructional goal and process used to help engage you in reflection about teaching and learning which you experience in this course and in the natural laboratory of your student teaching setting. The focus on experience in this course comes from the philosophic tradition of phenomenology which begins with the proposition that all human knowledge is based on experience that is lived. From the point of view of this course, the quality of that experience can be enhanced when you as student teachers, personally and autonomously, come to understand your own lifeworids and how these are connected 
with taking action in the everyday lifeworld of teaching. This will necessarily entail a personal search, a search for meaning wherein a central question for you will be-What, in my existence as a person, in my relations with others, in my work as a teacher, is of real concern to me and what sense can I make of it? Inquiry into the meaning of one's existence, ways of being, is essential to the concept of experience just as much as are ways of knowing. Together they form the basis for the study of teaching which allows for the integration of knowledge about teaching with the subjective organization and experience of being teachers.

Six persons comprised the course, wherein my approach to teaching and research with them was driven by the phenomenological question: What is it like to be a student teacher? What is it like to experience student teaching? As a way of access to their lived experiences, I asked them to write daily descriptive accounts of their experiences in teaching, a dialogue journal of sorts, wherein I sometimes made written comments to their writing, and other times used supervisory conferences for my response. I kept a descriptive journal, as well, of my experiences in teaching this course, which was also shared with the student teachers for their responses. Others have used dialogue journal writing focusing explicitly on the conversations as developed in the journals (Roderick, 1984) or in the broader sense of biographies-narratives as the formative history of an individual's life experience (Butt, 1984). The intent is to look at everyday life experiences of teachers through their voices as they experience them. This paper focuses on these descriptive accounts in the attempt to see how these students experienced teaching, for the potential recovery of their person and core of being in their reflections on their pedagogical practice. It should also serve as an opening of the way for questions to consider as we seek to create conditions for student teachers that will help them become more critically reflective persons in recognition of their being.

\section{Getting Started}

As a starting point of how we came together as a group, reflections from my journal display the tone created for the journey on which we were about to embark. Italics will be used to indicate the text of the written descriptions.

\section{Where Have all the Joys Gone? Degrees of Apprehension}

Having spent a lot of time orchestrating the conceptual framework for the course to reflect my concerns for "student teachers as persons," I was excited about meeting once again with students whom I had had in class, now almost two years ago for some. I had fond rememberances of excited dialogue with them about home economics and teaching when they were at the beginning of their teacher preparation. I was heartened by their familiar faces as we exchanged greetings. I always struggle with ways to begin the first 
day of class in the way of making introductions-especially for those who might be new to a group. I want to find ways for each person to reveal something about himself or herself in ways that are not so straightforward in the reporting factual sense. I like for something of one's self to be revealed. So I decided to begin the class by sharing a gift I had received which was a miniature desk with various remnants of school attached (apple, paper \& pencil, Tic-Tac-Toe, etc.) and asked each person to share both a joy and an apprehension that the desk reminded them of as they were about to begin student teaching. I was mortified when I heard several say that their only joy was that it would soon be over! These were not trite responses made for shock or laugh value, but they reflected sincere pain about the forthcoming teaching experiences. It was almost as if life had drained from them and it was quickly draining from me as I listened to their negative experiences about what they had or had not learned in their education courses. What had teacher education done to them? After the initial jolt in hearing this litany about the "wasted time in education courses" I experienced a great sadness about education. I moved, then, to feeling even more committed to the pathway I had chosen to approach this course from-reflecting on experiences to restore a sense of the person in teaching. I thought this was being received somewhat skeptically by the class and yet I was feeling their need to want to connect back to some meaning. But as I continued to talk about the framework for the course, I kept feeling I was running up against a barrier as I tried to share my enthusiasm about teaching and our work together and still meeting with the barrage of negative feelings. Could I ever begin to break through that barrier? Could I change their feelings about teaching? Should I change their feelings? I was beginning to feel a sense of frustration with my excited hopes about our work together being beaten down. I wanted to say, don't you have anything positive to say? But then I was asking them to be honest in their feelings, so why should they say something to make me feel good? My challenge was to try to break through what is at the root of the negative feelings-to understand them should be my first concern-not to change them. I shared with them my concerns about humanizing education-I felt a glimmer of hope that we can restore the humanness that seems to have been lost from their encounters with education via university teacher preparation. My closing plea as they went out the door, ready to face their first day in the schools the next morning was-I hope you find some joyful surprises!

Teacher as Stranger: The First Day in the School

As the student teachers reflected on the first day in their classrooms, their apprehensions and struggle to find their way from an outsider looking in were apparent. The following are some of their written descriptions of this experience. 
As I walked into the school I found myself feeling glad I was carrying a notebook and I knew my way to the classroom because I didn't want to be easily recognized as a visitor. I had feelings of denial when my cooperating teacher introduced me as Miss $N$. I almost blurted out - please call my by my first name (I'm not that old!).

4th period class! My God I never want this class! One boy/man (a repeat ninth grader)... rubs me the wrong way. I can see we might have a personality clash here. I must not let myself prejudge at this point - maybe he is just defining his space.

The first feeling of the day was excitement at starting something new which gave way quickly as I walked into the school. I also feel uneasy in the role of "new kid on the block" and today was no exception! Everyone was pleasant but busy, and for the most part I felt somewhat in the way.

When my cooperating teacher introduced me I sensed a feeling of intrusion from her students. I feel I am very different from my cooperating teacher in terms of personality, and I feel the students are already disappointed in having me there.

When I entered the room I felt very awkward-like I didn't belong. When the students were coming in they gave me different kinds of looks which made me feel uncomfortable and alienated. When my cooperating teacher introduced me to the class I smiled and thought to myself, "What am I doing here?"

The Unfinished Symphony

The following is my written description after day two of the class in which we discussed their written descriptions of the First Day in The School.

We met again-Day \#2! I approach the class with a sense of dread as I have been trying to shed the negative overtones from the last class. But as I think about what my plans were for the day I gain excitement again. We were to look at their written descriptions of "What I Experienced My First Day of Being in the School." This is the sort of work I like to do with students-phenomenological descriptions! We begin to analyze themes from their written work, but alas, the negative gloom seems to raise its head again-the theme of apprehension is loudest once again. We look at what is under the theme of apprehension-and this time the "fear of the unknown" seems to account for it. That is not so surprising. So I think well, my readings I chose for class today on "Teacher as Person" and the "Lived World of Teachers" will help uncover some of that unknown. I make an attempt to bring in their interpretations of the readings in relating it to themes on the board, but I feel a sense of dangling pieces not fitting together. Maybe they cannot yet really articulate the unknown because they have not experi- 
enced it! I leave the class with a sense of "The Unfinished Symphony!"

The Embellishment of Chords Left Unfinished

I invited persons in the class to read my first couple of journal entries and to share some of their responses in return. The following were some of their reflections.

This first class brought me many anxious feelings and they obviously showed through. Everyone was anxious and scared. It must have been difficult for you to hear these and still be positive. The frustrations you felt on this day were well hidden to me-you continued to be positive. I appreciate the way you reflect back to how we feel, and your efforts to understand us. Our frustrations need to be verbalized because of our upcoming new and frightening experience.

The openness of your journal and your ability to know our feelings surprised me for some reason. I guess it's just wierd knowing how your teacher reacts to a class. Our negative attitudes come from being scared because of lack of experience. Myself and possibly the other students came across confused and worn out because we are being pulled in different directions as far as what is expected of us. We want to do a good job to make ourselves feel good; we want our students to learn the most they can; and we have to organize and create lesson plans that our supervisors will be happy with.

I feel bad for having been one of the ones to deflate your bubble of excitement! But I think it was good for you to see how unprepared most of us feel for this semester. If we had been training for a particular job (such as secretary) I think we would have had specific skills and feel more confident. With teacher education, everything seems to be done in the abstract and that's probably why we feel uncomfortable.

Boy do I feel quilty! I feel like we have been unloading on you and not truly appreciating your position. I can imagine your frustration even as a veteran teacher who has prepared sooooo much to hear our negative comments. I don't think we really are negative as much as scared. We are feeling vulnerable and that makes us uncomfortable. Unfortunately we target those frustrations onto you. If it is any consolation we do it because you are our source of security. We trust you and feel we can be honest. We aren't sure about our cooperating teachers. They for the most part are an unknown so we cover up our true feelings and attempt to present a positive can do attitude. The journal has been a real eye opener, both from the standpoint of our journals where you give us feedback and the opportunity to read your journal so we see "teacher as person." I hope your frustration gives way to a feeling of success as you guide us through the experience. 
Feeling Caught in a Big Lesson Plan-What a Nightmare!

In recognition of our different starting points, the following reflection comes from my journal after the third class we had together.

I begin the class sharing my sense of unease and "The Unfinished Symphony" effect-and reveal my recognition of our being in two different places-our needs and expectations clashing rather than meeting. One student says it well: "I need the security first about knowing what I am going to teach-then I can concentrate on person and my self." This is quite an irony as we talk about selfactualization. I am pulling toward the top of Maslow, while they really do not have the lower needs met-a sense of security to guide them in their teaching. The Unit Plan is all encompassing of their thinking at this point. This is the supreme frustration for me. I recognize this need, yet I want to provide the security through other means than the technical plan. How do we move beyond that focus to get them to experience teaching as it unfolds rather than to have everything predetermined? Am I failing to give them what they feel they need-I feel the pull of the They-Other. Can I resist that long enough to allow other aspects of teaching to emerge? We have a good discussion about "The Lifeworld of Classrooms"-the readings assigned. I feel as if we made connections-but are they really hearing this, or are their minds too busy attending to the noise created by lesson planning? I talk of my concerns with friends at lunch. They are surprised when I tell them I have readings as a focus. They too sense the real world concern of surviving teaching concerns of students. There has to be some kind of mid ground point for building from an experience base. I begin to give in though as I preface my remarks with-next time we will help you begin a structure for your teaching and planning. Why do I resist that so strongly? I feel caught in a big lesson plan-what a nightmare!

A student responds to this entry in the following way:

At times I feel you are disappointed with us because we are so intent on technical content. I feel for you in that you would really like to take us to a higher level, but we are stuck on a lower level that is also the level of our schools so it is even more difficult for us to try to move to your level. I do appreciate your insights and comments during class and on my papers. I know that we must develop a higher level of learning and I know I will strive for that as soon as I am comfortable with "Me as Teacher." Don't despair, we heard you!

In my attempt to focus on their experiencing of classroom events, in the words of one student, "that we lay back and experience teaching and ourselves as teachers and persons," maybe I was missing a big chunk of their inner core-a secure base from which to anchor the exploring! In the words of the same student, "The reason we are so anxious or nervous about planning is because it is a big cloud 
hanging over our head. We realize the work involved and we are yearning to feel some relief." I am struggling to move away from a how-to-do-it emphasis and they are pulling toward that focus. Should there be more of a compromise? That tug and pull of these competing forces find a somewhat balanced tension throughout the semester, as the following themes emerge as voiced in the descriptive writing.

\section{On the Way to Being and Becoming: Pedagogical Reflections}

The reflections on experiences throughout the semester revealed many insightful themes as voiced in their own expressions. The following are some of the themes I found most revealing of their experience of student teaching that speak loudly to those of us who are in positions to help teachers in their becoming. The titles used came from direct quotes in the students' writing.

\section{"I Don't Know Whether to Commit Suicide or Go Bowling!"}

I really dislike doing things I can't do well! I seem to be feeling a sense of annoyance from my cooperating teacher. I am trying to be polite but am feeling a sense of frustration in getting direction from her. I get the feeling she thinks I should just jump in-sink or swim! I will probably have these feelings until I have more of a structured plan. I dislike being understress and the one way I can avoid stress is to be well organized.

Do it Your Own Way, but Make Sure it's Our Way!"

My frustration stems from the fact that I feel at a disadvantage in the seventh grade class. All the teachers have been doing this for years and I don't automatically know the system! I'm being told to do it my own way but the real message is "Do it your own way but make sure it's our way!" I will always do it differently since I go first and have never observed this unit! I'm feeling a little sense of gloom and doom!

\section{"I Have so Much Still to do Before Monday!"}

Again it seems as if time is always pressing in. I do feel there is so much I don't know how to do. I am so glad it's Friday! I need time to look over my plans again and see if there is some way to make them more related to the kids' lives. I need so much time still to work on lessons. This work is difficult for me-I don't know how I am going to be able to handle three preps, but I can't think about that now. I am letting the pressure get to me and I must back off for awhile and regain my perspective-but what is the perspective I want?

"And What About Higher Level Questions About Casseroles?" I just don't know why I can't get excited about the subject matter this week (main dish casseroles!). I find the lessons uninspiring and wonder how to present this very technical topic in an untechnical but interesting way. Another lesson that was boring 
was time management. My first impression is that I just didn't enjoy the topic and maybe the kids saw that in my presentation. Now that I have seen what happens when lessons are boring and do not relate to students' lives, I need to make sure mine are not like that anymore.

\section{"It's Like Falling in Love With Your Doctor!"}

My cooperating teacher and I have had more time together. We seem to have a good rapport and get along well together. I admire her style and ease and find myself copying her. Is that normal? Like falling in love with your doctor?

\section{"Sometimes Dr. H. Doesn't see Where we are Coming From"}

We have to give our cooperating teachers what they are looking for-if not we may end up alienating them. And it sounds as if most of our cooperating teachers want something that isn't always along the new thinking of home economics. We are too vulnerable at this point to break the system no matter how much we may want to.

"I Guess I Still Don't Want to Assume Responsibility of Being a 'Real' Teacher"

Last university class tomorrow-I pulled in a lot from other people's ideas and questions to get a wider view-who will I use as resources now? Who will I lament, complain, and share with? I'm not ready to cut loose-I liked the security of having someone oversee my work and mistakes. I always felt better after seminars. I see everyone else struggling and don't feel quite so dumb at not having my act together.

\section{"Now I can see why People get Hooked on Teaching!"}

Good day today! Now I can see why people get hooked on teaching. I used an activity that the students really enjoyed and I honestly felt like they learned something. It was an exhilarating experience! I wonder what percentage of time teachers feel like this? I needed this today.

"I Must Admit I am Finding That I am Enjoying This Teaching Experience More and More"

Outstanding day today! I used an idea from the mainstreaming conference which generated good discussion on learning disabilities. Several of the girls have brothers or sisters who have learning disabilities and they shared with the class some of their frustrations of the family members as well as the child himself. My frustrations have very little to do with teaching itself but rather the time and a feeling of not being able to do things as I want to do them. 
"Today was the Day Mr. K. Paid me a Visit!"

When I was giving my lesson I did not make it a point to look at him. When he got up and left halfway through it rattled me. I initially felt, oh God, I was doing so bad that he couldn't stand to watch me any more. When he discussed his observation with me sixth period, his manner was cold, business-like, and impersonal. I felt like crying but it's difficult for me to cry. I had to talk to somebody so I went up to guidance and talked to my old roommates' mother. Another visit by Mr. K! He didn't say bye when he left. I feel as if I'm such a burden to him-having to waste his time watching me fulfill a duty he doesn't have time for. He never told me why he left yesterday.

"I Don't Know if the Kids Learned Anything, but They Took Notes!"

I felt I accomplished something today. I don't know if the kids learned anything, but they took notes! I saw more notes taken since I'd been here. And John, my problem student, took notes too. He told me he doesn't take notes in any class. As far as I am concerned, I've made a real break through. At least with John he usks me questions and seems to want to become more involved.

"Today was a Horror Story!"

Things were going smoothly until I got a note from the office for my problem student. The student refused to go to the office. I explained to her calmly that it would be best for everyone if she went. She told me to shut up and to calm down-among other things! I tried to calm down but she continued yelling and I left the room. My cooperating teacher called the office for security, and they removed the student from class with quite a fight. The student will not be returning to class and may be expelled. I didn't sleep much that night!

"I Feel the Classes Have all Accepted me as Teacher"

I feel like a teacher, not a student. I am having no trouble at all in assuming this role. In fact I like it! I am respected by these students (or at least feel like I am) and they seem to like me.

"I Became Mean Because I Felt the Students Didn't Deserve my Kindness"

Everything went well until sixth period (eighth grade!) The students chattered throughout my entire lesson. No matter how many times I asked them to pay attention or stopped until they gave me their attention, they would not listen. By the end of the period I was very frustrated. I became mean because I felt they did not deserve my respect and kindness. I felt hate for them. I find it difficult to keep myself from feeling this way. The ironic thing is that after 15 years of teaching, my cooperating teacher doesn't even know how to handle them. What should I do? 


\section{"I Like it When You Come to Visit"}

I'm glad when you come to visit. I enjoy having you here. I feel secure when you are here-like you are my protector.

\section{Reflections and Insights}

T.S. Elliot speaks directly to my insights gained from this experience with student teachers:

We shall not cease from exploration.

And the end of all our exploring

Will be to arrive where we started

And know the place for the first time.

From where did we start this journey through the student teaching experience? Fear of the unknown, apprehension, strangers, feeling vulnerable, might all be characterized as the "mood of anxiety" (according to Heidegger) which I described as a positive theme for work with student teachers. This kind of anxiety (existential) is a means for opening the way to that which we are. "To give up that which we know or are for that which we do not know or are not yet is threatening. The lure of the transcendent must be present for education to happen, but that lure is threatening" (Huebner, 1984, p. 117). Education, then, is not only a leading outward of who we are, but also a leading toward that which we are not. This threat of the unknown was very real and expressed in many different forms (as the titles and text in the previous section indicate). In all of our exploring together, this anxiety seemed to be continually present, but it was faced with a realization that I chose to display in the closing student teacher reflection: "I'm glad when you come to visit-I feel secure when you are here." The existential meaning of this is found in Huebner's talk about the presence of otherness and caring:

How can we face the threat of the unknown and the stranger outside of us and inside of us? It is not easy. We need the assurance that we will not be destroyed, that life will indeed be enhanced rather than destroyed.... We can face the threat of the unknown and of the stranger if we are not alone. (p. 117)

As I sought to create an environment where this sense of caring and otherness would be present, I made conscious choices in my rejection of some of the more technocratic approaches to teaching and the thing-like language of mainstream educational psychology. In turning to a phenomenological framework, I was more concerned with language expressive of persons and experiencing. I clearly heard the words of Palmer (1983) in a chapter entitled "To Teach is to Create a Space" wherein space signifies the experiences of everyday life. As we open up to our experiences, ideas and feelings arise within us as our knowledge comes out of hiding. The dimensions of 
such a space called for by Palmer would reflect three major characteristics of openness, boundaries, and an air of hospitality. As I reflect on those dimensions now, they serve to illustrate what I think stood behind our experience together in this class, and for the potential they might reveal about a being focus.

Openness, according to Palmer, is a commonsense meaning of space, wherein to create it entails the removal of barriers to learning we find around us, behind which we hide so that truth cannot seek us out. My idea of opening the space for learning was the reduction if not removal of technical lesson plans so as not to pack the learning space with techniques nor to become absorbed with method seeking. This openness at first was welcome but it soon became threatening, for when the clutter of exact formats was removed, it also removed a focus for keeping the mind employed on technical detail-and that returned a focus on self and the sense making of the experience. My struggle in throwing off the technical was clearly felt as I heard their cries for structure, or as in the words of one student teacher: "I need the security first of knowing what I am going to teach-then I can concentrate on my self." This response fits only too well with the stage socialization theories we hear of so often in regard to student teachers, where the concern first is said to be preoccupation with self and measuring up to the expectations set by others in order to prove competence (the technical mentality). This concern for self is very different from the existential confrontation with self and becoming. Concerns, then are said to lead to what is actually taught and finally to the students. If we continue to perpetuate that order and form of student teacher concerns, we merely fit them to the conservative and established patterns of school practice rather than help them to become more reflective, experimental, and active in their approach to teaching and education.

Boundaries, on the other hand, suggests Palmer, must define the learning space so that it will be kept open and also keep students from fleeing that space. This kind of boundary, however, does not suggest rigid structure, but a persistence of staying within the learning boundaries one seeks to confront: How does the experience present itself for truth to be sought out rather than being covered up? What do we see in and learn from the experiences as we confront self in the process? My boundaries became the steadfast examination of experience within the context of a laboratory setting, a place to experiment by a gradual assuming of responsibility for teaching as opposed to the apprenticeship concept: immediate proficiency in all classes for the application of theory, teaching skills, and management (Adler, 1984). This approach was met with some resistance by the cooperating teachers who believed the true test of becoming a teacher was to pass all the hurdles they experienced as student teachers in order to become technically proficient. The measuring gauge of a successful experience was almost viewed as the amount of 
pain and pressure one could withstand-on one's own-and still manage to do things technically well.

Hospitality, according to Palmer, is necessary precisely because a learning space can be a painful place. But it has a different motive and form of display than what the cooperating teachers had in mind. Hospitality, in creating an open space, means receiving one another-the struggles, the new and experimental ideas-with openness and care. Our seminars served that purpose as expressed by one student: "I always felt better after seminars. I see everyone else struggling and don't feel quite so dumb at not having my act together." As Huebner (1984) suggests, "Those who claim to be educators must care for, indeed love, those whom they would presume to educate" (p. 118). Caring in this sense, then, provides a way to help make more meaningful the threat of the unknown as it leads outward to that which we are not in our process of becoming.

White (1984) describes the journey of becoming a teacher as a series of dilemmas that student teachers confront in the field, three of which were particularly relevant here. The first involves the dilemma of wanting to be liked and perceived as nice while at the same time maintaining control of the group. I heard this dilemma reflected several times in comments like the following: "I became mean because I felt the student didn't deserve my kindness"-or "I don't know if the kids learned anything but they took notes!" A second dilemma occurs with regard to the infinite amount of time and energy that is demanded with a limited amount available, as reflected in comments like the following: "I have still so much to do before Monday" or "My frustrations have very little to do with the teaching itself but rather the time and a feeling of not being able to do things as I want to do them." Compounding this dilemma was the balancing of family responsibilities with school responsibilities. A third dilemma relates to the possible options for curriculum choice where a different type of organization is needed or desired by student teachers as contrasted with the more experienced cooperating teachers. Comments like the following reflect this dilemma: "We have to give our cooperating teachers what they are looking for-if not we may end up alienating them," or "I just don't know why I can't get excited about the subject matter this week (main dish casseroles!)." The dilemmas serve to confront a receiving view of teaching knowledge as a set of accumulated skills with the very reality of "persons as teachers" constructing their knowledge of teaching in process.

My dilemmas as instructor of the course and supervisor of the student teaching experiences were very real also. My dilemma might be likened to the polarity created by two competing conceptions of teaching as described by Koehler (1984): First, teacher education to prepare individuals to change and improve education, and second, teacher education based on the research findings of the skills, 
behaviors, and knowledge of effective and experienced teachers. I sought to help student teachers move away from the utilitarian perspectives of teaching (Goodman, 1985) - for example, teaching as a technical activity of management-and at the same time felt the tension created by the pull to fit in to the predefined patterns of conduct found in the schools established by the knowledge of experienced teachers. My dilemma was enhanced as I responded to the very real pull of student comments like the following: "We are too vulnerable at this point to break the system no matter how much we may want to." I persisted on the belief that if we are ever to shift our focus from the technocratic mentality in teacher preparation, we must move toward attempts at understanding our practice as we seek to promote a more critically meaningful educational experience for preservice teachers. In that attempt, I too experienced the threat of not knowing, and in the process my own existential anxiety was uncovered in the encountering of something that matters to methe real power of our becoming together as teachers, breaking with predefined categories of seeing. In all of our exploring together, then, as we arrived at where we started from (fear of the unknown and anxiety), what did we really know of this place for the first time? It has to do with how our anxiety and stress were confronted. Cunningham (1983) describes the most significant source of stress and disenchantment for teachers as their "unwitting abdication of their right to personhood - the right to experience self as a human being" (p. 3). I would suggest that we came to feel at home with anxiety, and it became a positive way of access for the emerging of our persons as teachers and the sense of making of our experiences together in the doing and being of teaching.

\section{References}

Adler, S.A. (1984, April). An historical analysis of early field experiences. Paper presented at the Annual Meeting of the American Educational Research Association, New Orleans.

Butt, R.L (1984). Arguments for using qualitative approaches in understanding teacher thinking: The case for biography. Lethbridge, AB: University of Lethbridge.

Cunnigham, B.A. (1983). Teaching as being: The right to personhood (Occasional Paper No. 6). Edmonton, AB: University of Alberta.

Denton, D.E. (1974). That mode of being called teaching. In D.E. Denton (Ed.), Existentialism and phenomenology in education. New York: Teachers' College Press.

Goodman, J. (1985, April). Making early field experiences meaningful: An alternative approach. Paper presented at the Annual Meeting of the American Educational Research Association, Chicago.

Huebner, D. (1984). The search for religious metaphors in the language of education. Phenomenology + Pedagogy, 2(2), 112-113. 
Hultgren, F.H. (1982). Reflecting on the meaning of curriculum through a hermeneutic interpretation of student-teaching experiences in home economics. Unpublished doctoral dissertation, Pennsylvania State University.

Hultgren, F.H. (1985). Syllabus for EDIT 342: Curriculum, instruction and observation: Home economics education. College Park, MD: University of Maryland.

Koehler, V. (1984, October). Research on preservice teacher education. Paper presented at the National Conference on Teacher Education, Austin, Texas.

May, W.T., \& Zimpher, N.L. (1985, April). Perceptions of preservice field supervision: A call for theoretical recognition. Paper presented at the Annual Meeting of the American Educational Research Association, Chicago.

Palmer, P.J. (1983). To know as we are known/A spirituality of education. San Francisco: Harper \& Row.

Roderick, J.A. (1984). Perspectives on self as teacher: Cracks in the technocratic (Occasional Paper No. 28). Edmonton, AB: University of Alberta.

Tom, A.R. (1985, April). Inquiring into inquiry teacher education. Paper presented at the Annual Meeting of the American Educational Research Association, Chicago.

van Manen, M. (1984). Practicing phenomenological writing. Phenomenology + Pedagogy, 2(1), 36-69.

White, J.J. (1984). Passage to professional: Elementary education students' induction into the culture of teaching. University of Maryland, Baltimore County. 